\title{
Research on the Construction of Practical Teaching System of Tourism Major in Higher Vocational Education
}

\author{
Binbin Fan \\ Shaanxi Youth Vocational college, Shaanxi Xi’an 710068, China
}

Keywords: higher vocational education; tourism major; practical teaching; system construction

\begin{abstract}
Tourism is one of the industries with vitality and potential in the national economy and in the composition and development of the industry. Its economic profits are enormous and can not be ignored. With the current constantly changing market economy, the tourism industry continues to optimize and restructure, and the demand for talent has changed. In this situation and background, the plan of vocational colleges and universities in the training of tourism professionals also need to be adjusted, especially the construction of the whole professional teaching system. This paper mainly focuses on the practical teaching system of tourism major in higher vocational colleges and universities, discussing the basis of its system construction and the existing problems, and offers some suggestions on its system construction.
\end{abstract}

\section{Introduction}

The development of the tourism industry can't do without the professional and outstanding talents, especially the talents who are with the solid theoretical knowledge and strong practical ability. Therefore, higher vocational colleges must pay more attention to the cultivating of the professionals. In the education and training of talents, higher vocational education has always upheld the principle of "improving the professional practice ability of students, emphasizing practical teaching and vocational skills training, to cultivate the talents who can meet the needs of social development. This is also the characteristics and vitality of vocational education. As a result, the construction of practical teaching system of tourism in higher vocational is inevitable and required.

\section{Practical Teaching System and Construction Basis of Tourism in Higher Vocational Education}

In the higher vocational education, the practical teaching system mainly refers to a more completed practical teaching activities plan, which is developed by the school in different major, in order to achieve the purpose and requirements of education and teaching. The teachers help students who are with a certain theoretical knowledge to practice, which are based on the practical teaching arrangements. The distinctive characteristics of the practical teaching system are as follows:

\subsection{Integrality}

Take the practical teaching system of tourism in higher vocational as the example, the content of this system is relatively complete. It includes many teaching modules of different functions. These teaching modules are targeted in separated, and comprehensive in combined [1]. The specific content contains mainly the following modules:

1) The module of cognition teaching in major. The students are arranged or required to know the travel industry and travel agencies in school. The practice often be implemented in the winter and summer vacations;

2) The module of theory and practice teaching. The module is related to a lot of content, including the basic theory courses of tourism, practical teaching in classroom, training teaching and so on. This module is very important to the students. Teachers need to organize or arrange different forms of teaching, for example, arrange students to introduce a scenic spot, or allow students to deal 
with problems arising in the tour group;

3) Professional practice and graduation practice. The students need to learn ceremonial reception, simulation and other knowledge of tourism [2]. This happens in the graduation period, completing each requirement for graduation. Students also need to submit reports and other papers.

All the above, we can find out the integrality of practical teaching system of tourism in higher vocational, and the content of this system is more meticulous.

\subsection{Strongly practical and operable}

Higher vocational education attaches great importance to cultivate the practical talents. It strengthens the operability in the class plan of practical teaching.

Take the students' graduation practice as an example, the school has some arrangements and requirements of graduation practice for tourism students, they are the following:

1)The specific time arrangements of graduation practice. It is always in 1-2 months before graduation. Students can be fully energetic in the internship without theoretical courses in the period.

2) On the basis of the cooperation between the school and enterprise, the students can practice in the cooperative enterprise or travel agency, and be helped by someone in the enterprise;

3) For Tourism students, graduation practice report and graduation thesis are needed to assess their practice.

All the above, the practical teaching system of tourism major in vocational colleges is of great help to improve students' professional knowledge and skills, and through practical teaching, students can gradually form a certain sense of occupation, ethics and professional skills.

The construction of practical teaching system of tourism in higher vocational is necessary in the current society and the education system. The bases are as follows:

(1) The demand of the market and the industry for talents: the current market and industry require tourism talents with high practical ability. According to the survey of the demand of tourism professionals, students should have the ability of computer operation, certain language ability and so on $[3,4]$. It shows that the tourism in higher vocational school must construct the practical teaching system.

(2) The requirements of the characteristics of higher vocational education: One of Higher vocational education's objectives is to cultivate practical talents. Higher vocational education is different from ordinary colleges, which focus on the professional theory of pure academic education teaching. And it is also different from the secondary level of pure operation-oriented personnel training. Higher vocational education has its own unique point of personnel training, that is, the main training of high-quality professional and technical personnel, who are the technical backbone and management in production, management, service front-line. The practical ability of students relates to the future employment of them and the employment rate of vocational schools. Therefore, the construction of practical teaching system is very important.

(3) The requirements of the nature of tourism major: The purpose of tourism professional learning is to acquire the ability of being engaged in the industry for students. The employment positions in tourism include the tour guide, the transfer, customers management. Different employment positions require different knowledge and skills. Therefore, the construction of practical teaching system requires the differentiation of knowledge and skills, but also the appropriate integration.

\section{Problems in the Construction of Practical Teaching System of Tourism Major in Higher Vocational Education}

In fact, China's tourism vocational education has been built a relatively perfect practice teaching system. In the system, some vocational schools have achieved better results in teaching and employment [5]. At the same time, we should pay attention to constantly improve the system to keep up with the development of the times, and to maintain a better vitality. Therefore, we need to analyze the existed problems firstly. They are as follows: 
Although the practical teaching system of tourism is operable strongly, the content can not fully reflect the local characteristics, and be lack of integration with local tourism.

Take an example of guide practice teaching. Students learn a wide range of theoretical knowledge of the tour guide, including many attractions in China, the introduction of the region, handling of emergencies during the tour. In the simulation guide practice class, students can choose their favorite topics to simulate, which can fully mobilize their autonomy and enthusiasm. On the other hand, the students are lack of focusing on the local tourism industry in this kind of practice teaching method, including the hot issues and the direction of development. It leads to insufficiency combination between the practical teaching and reality, and impact the student in simulation of guide, especially the difference from life practice.

The school should provide students with a certain platform and opportunity in the construction of tourism practice teaching system. However, some vocational colleges do not establish a sound training base. In many cases, the practice teaching is mainly dependent on teachers' guide in the classroom. Due to the lack of platform and the real practice environment, students can not fully be aware of the importance of practice in the tourism practice teaching, effecting the result of practical teaching [6,7]. Although many vocational colleges in China will provide restaurants, guest rooms, physical rooms and other places, some of them do not make full use of these places for practical teaching, resulting in the need of improvement of tourism professional practice teaching.

\section{Suggestions on the Construction of Practical Teaching System of Tourism Major in Higher Vocational Education}

According to the above elaboration and analysis, the construction of practical teaching system of tourism can be improved from three ways:

We can take measures are as follows: (1) The school should consider with the fact, and adjust practical teaching outline, instruction book, plan, practice teaching procedures, daily teaching management, practice teaching. (2) Teachers should combine the practice teaching content with the actual, for example, combine the content with the hot and key issues of local tourism to aware the students about industry dynamic, and put them in practice fully.

In order to effectively improve the practical ability of tourism students, the school should constantly improve the corresponding platform in the process of building a practical teaching system. It is effective to train students' professional awareness and vocational skills. The concrete measures are as follows: (1) Higher vocational colleges can fully rely on the cooperation with enterprises, optimizing the practical resources, to provide students with corresponding practical platforms; (2) Higher vocational colleges should apply the existing practice platform fully, facilities and equipment, such as organize practical teaching more often in the dining room, guest rooms and other places; (3) Higher vocational colleges should increase investment in practical teaching for students to establish a sound practice, training base and place.

It needs a feedback mechanism to know whether the construction of the practical teaching system of tourism students meets the needs of them, and the needs of the development of the times. There are some ideas: (1) assessing the result of students and teachers in practice teaching, including students' professional results and teachers' teaching evaluation, etc. (2) vocational schools can establish a special assessment group of the teaching practice of tourism to assess the professional teaching and employment. We can get the feedback of practice teaching process and result through the above measures, and then continue to improve the practice teaching system.

\section{Conclusion}

In summary, the current tourism industry needs practical and professional talents. The vocational colleges should construct more perfect system of practical teaching. I hope the above research and discussion would provide some reference in the construction of practical teaching system of tourism major in higher vocational education. 


\section{References}

[1] Liancheng Wei, Research on the construction of practical teaching system of tourism in higher vocational education - taking "tour guide" as an example [J]. Business Economics, 22: 116$117,2011$.

[2] Qing Li, Li Li, Research on innovation of tourism management professional practical teaching system[J]. Journal of Chongqing College of Education, 06: 54-57,2011.

[3] Wenming Li, Huayin Xiao, Jia Zhan, Discussing of innovative way On the practical teaching management of tourism management in vocational education [J] Vocational Education Forum, 36: 80-82,2011.

[4] Xiaolong Jia, Hongsheng Cai. Analysis on the construction of practice teaching system of tourism management in vocational education [J]. Education and occupation, 15: 167-168,2010.

[5] Baijun $\mathrm{Wu}$. The research on practical teaching system of tourism management in higher vocational education [J]. Modern Educational Science, 01: 85-88,2015.

[6] Qinglan Wu, Qiaohua He, The construction of practical teaching system of tourism management in higher vocational education [J]. Xiangyang Vocational and Technical College, 06: 121-123,2015.

[7] Wangdong Shi. The reflection and exploration on the construction of practical teaching system of tourism management in higher vocational education [J] China Education, 21: 144,2012. 